\title{
Factors associated with the functional capacity of older adults with leprosy
}

\author{
Fatores associados à capacidade funcional de idosos com hanseníase
}

Factores asociados a la capacidad funcional de las personas mayores con lepra

\section{Paula Sacha Frota Nogueira', Marilia Braga Marques', Janaina Fonseca Victor Coutinho", Juliana Cunha Maia', Maria Josefina da Silva", Escolástica Rejane Ferreira Moura"}

\author{
'Universidade Federal do Ceará, Faculty of Pharmacy Dentistry and Nursing. Fortaleza, Ceará, Brazil. \\ "Universidade Federal do Ceará, Faculty of Pharmacy Dentistry and Nursing, Postgraduate Program in Nursing. \\ Fortaleza, Ceará, Brazil.
}

\section{How to cite this article:}

Nogueira PSF, Marques MB, Coutinho JFV, Maia JC, Silva MJ, Moura ERF. Factors associated with the functional capacity of older adults with leprosy. Rev Bras Enferm [Internet]. 2017;70(4):711-8. [Thematic Edition "Good Practices: Fundamentals of care in Gerontological Nursing"] DOI: http://dx.doi.org/10.1590/0034-7167-2017-0091

Submission: 02-15-2017 Approval: 03-18-2017

\begin{abstract}
Objective: to investigate the association between socio-demographic and clinical factors and the functional capacity of older adults with leprosy. Method: cross-sectional analytical study conducted in Fortaleza, Ceará, Brazil, with 77 older adult patients with leprosy in a referral service, through interview, medical records and application of the Katz Index and the Lawton and Brody Scale. Results: the mean age was 68.23 years, with prevalence of men, in stable union/married, with mean monthly family income of 2.04 minimum wages, positive bacillary index, clinical dimorphic form and grade zero disability. In the Lawton and Brody scale, independence $(58.5 \%$ ) was predominant and associated to the variables "living arrangement" and "educational attainment". Total independence (87.0\%) was predominant in the Katz Index and statistically associated to the variable monthly family income. Conclusion: most of the participants were classified as independent in the instruments used. Furthermore, the instruments pointed to a greater number of associations with socio-demographic and clinical factors not related to leprosy.

Descriptors: Older adults; Geriatric Assessment; Leprosy; Elderly Health; Mycobacterium leprae.
\end{abstract}

\section{RESUMO}

Objetivo: investigar a associação de fatores sociodemográficos e clínicos à capacidade funcional de idosos com hanseníase. Método: estudo transversal, analítico realizado em Fortaleza, Ceará, com 77 idosos com hanseníase acompanhados em serviço de referência, através de entrevista, consulta ao prontuário e aplicação do Índice de Katz e Escala de Lawton e Brody. Resultados: a média de idade foi de 68,23 anos, com prevalência de sexo masculino, união estável/casado, renda familiar mensal média de 2,04 salários mínimos, índice baciloscópico positivo, forma clínica dimorfa e Grau de Incapacidade Física zero. Na escala de Lawton e Brody prevaleceu a independência (58,5\%) com associação às variáveis "com quem reside" e "escolaridade". Destacou-se a independência total $(87,0 \%)$ no índice de Katz, associando-se estatisticamente a variável renda familiar mensal. Conclusão: a maioria dos participantes mostrou-se independente nos instrumentos utilizados. Ademais, os instrumentos apontaram mais associações a fatores sociodemográficos e clínicos não relacionados com a hanseníase.

Descritores: Idoso; Avaliação Geriátrica; Hanseníase; Saúde do Idoso; Mycobacterium leprae.

\section{RESUMEN}

Objetivo: investigar la asociación de factores sociodemográficos y clínicos a la capacidad funcional de los ancianos con lepra. Método: estudio transversal, analítico, realizado en Fortaleza, Ceará, realizado entre 77 ancianos con lepra mediante entrevista, acompañados en servicio de referencia, consulta al prontuario y aplicación del Índice de Katz y de la Escala de Lawton y Brody. Resultados: la edad promedio era de 68,23 años, con prevalencia del sexo masculino, unión estable/casado, renda familiar mensual promedio de 2,04 salarios mínimos, índice bacteriológico positivo, forma clínica dimorfa y grado de incapacidad física cero. En la escala de Lawton y Brody prevaleció la independencia (58,5\%) asociada a las variables "con quien reside" y "escolaridad". Se 
destacó la independencia total $(87,0 \%)$ en el índice de Katz, asociándolo estadísticamente a la variable "ingreso mensual del hogar". Conclusión: la mayoría de los participantes demostró independencia de acuerdo con los instrumentos utilizados. Además, las escalas señalaron un número mayor de asociaciones a factores sociodemográficos y clínicos no relacionados con la lepra.

Descriptores: Persona Mayor; Evaluación Geriátrica; Lepra; Salud del Anciano; Mycobacterium leprae.

\section{CORRESPONDING AUTHOR Paula Sacha Frota NogueiraＥmail: sachanogueiraufc@gmail.com}

\section{INTRODUCTION}

The increase in the proportion of older adults, observed worldwide, has a significant part in social, political, economic and health challenges. In developing countries, such as Brazil, these challenges are even more complex, as health services still do not have the necessary training to provide adequate care for the elderly population ${ }^{(1)}$.

Aging is distinguished by gradual and inevitable changes; this process produces alterations with potential to increase vulnerability and susceptibility to diseases in older adults. Some conditions are able to trigger a progressive functional impairment. The functional capacity measures the ability and independence for executing activities directly related to selfcare and social participation ${ }^{(1)}$.

Among the diseases that influence the functional impairment in older adults, leprosy (Hansen's disease) stands out, as it is a disease that might be incapacitating and cause physical deformities when not properly treated. This chronic, infectious, dermato-neurological disease compromises the peripheral nerves and might aggravate functional difficulties ${ }^{(2)}$.

Epidemiological data on leprosy show that Brazil ranks second in the number of cases detected in the world, representing $13 \%$ of new cases worldwide ${ }^{(3)}$, with the highest number of new cases being in the Northwest region ${ }^{(4)}$.

In patients with leprosy, evaluation of disability is part of the treatment, since the disease is capable of compromising important functions. However, it is important to note that older adults with leprosy, even those without physical disability related to the disease, may present a decline in their functional capacity, related to the aging process. This condition requires care and actions capable of identifying preexisting functional limitations that may or may not be increased by the disabilities generated by the disease.

Therefore, the objective of this study was to investigate the association between socio-demographic and clinical factors and the functional capacity of older adults with leprosy.

\section{METHOD}

\section{Ethical aspects}

The local Research Ethics Committee of the research approved the research project.

\section{Design, study locale and period}

Cross-sectional and analytical study, conducted in Fortaleza (in the state of Ceará) from June to August 2015, with users of a service specialized in dermatology, Ceará's Health Department reference unit for the treatment of leprosy, recognized by the
Ministry of Health as National Reference Center for Sanitary Dermatology. This center develops assistance, teaching and research activities in the area of Dermatology, aiming to develop and support health care policies, especially regarding leprosy.

\section{Population or sample: inclusion and exclusion criteria}

The study population consisted of older adults with leprosy, considering as older adults individuals who were 60 years old or older ${ }^{(5)}$. The inclusion criteria were: no auditory deficit and/or alterations that compromise verbal communication; and attending the unit for a consultation on disability prevention. The exclusion criteria were: attending the unit only for laboratory tests, dressings or medical appointments. The sample was calculated based on a $15 \%$ prevalence of the phenomenon, resulting in 77 older adults.

\section{Study protocol}

Data were collected through individual interviews, in a room in the outpatient clinic, after the subjects left the consultation. Subjects who met the inclusion criteria were invited to participate in the study. The interviews were conducted by interviewers previously trained by the research coordinator.

The forms used contained questions about socio-demographic factors (age, gender, marital status, origin, living arrangement, educational attainment, occupation, monthly family income) and clinical characteristics (blood pressure [BP], blood glucose, Body Mass Index [BMI], comorbidities). The Katz Index and the Lawton and Brody Scale were used to assess functional capacity.

For the evaluation of $\mathrm{BP}$, the subjects were classified as normotensive if, during the random check, they presented a Systolic Blood Pressure (SBP) $<140 \mathrm{mmHg}$ and a Diastolic Blood Pressure (DBP) $<90 \mathrm{mmHg}$, according to the parameters of the Brazilian Cardiology Society. The BP classification was: normotensive SBP $\leq 120 \mathrm{mmHg}$ and DBP $\leq 80 \mathrm{mmHg}$; prehypertension SBP $121-139 \mathrm{mmHg}$ and DBP $81-89 \mathrm{mmHg}$; stage 1 hypertension SBP $140-159$ $\mathrm{mmHg}$ and DBP 90 - $99 \mathrm{mmHg}$; stage 2 hypertension SBP $160-170 \mathrm{mmHg}$ and DBP $100-109 \mathrm{mmHg}$; and stage 3 hypertension SBP $\geq 180$ and $\mathrm{DBP} \geq 110^{(6)}$.

For the evaluation of blood glucose, the most recent fasting blood glucose test was considered, according to the following classification: normal blood glucose $(<100 \mathrm{mg} / \mathrm{dl})$, impaired glucose tolerance ( $>100 \mathrm{mg} / \mathrm{dl}$ to $<126 \mathrm{mg} / \mathrm{Dl}$ ) and diabetes mellitus $(\geq 126 \mathrm{mg} / \mathrm{dl})^{(7)}$.

For the calculation of the Body Mass Index (BMI), body weight was determined using an anthropometric scale and the stadiometer was used to measure height. The participant's BMI was calculated using the formula weight (in kilograms) divided by height 
(in squared centimeters). The specific parameters for older adults were used, classifying them as underweight ( $\leq 22 \mathrm{~kg} / \mathrm{m} 2)$; normal $\left(>22\right.$ e $\left.<27 \mathrm{~kg} / \mathrm{m}^{2}\right)$ and overweight $\left(\geq 27 \mathrm{~kg} / \mathrm{m}^{2}\right)^{(8)}$.

The Katz Scale comprises the Activities of Daily Living (ADLs), consisting of six items (bathing, dressing, toileting, transferring, continence control and feeding) ${ }^{(8-10)}$. For the results, we used the standardization proposed by the Hartford Institute for Geriatric Nursing, which classifies older adults as independent (six points), partially dependent (four to five points) and very dependent (less than three points) ${ }^{(11)}$.

The Lawton and Brody scale comprises instrumental activities of daily living (IADLs), consisting of nine items (preparing meals, housekeeping, doing laundry, handling medications, going to places requiring walking for long distances, handling finances and using the telephone). Each question admits three answers: "independent" (three points), "needs assistance" (two points), "unable" (one point $)^{(8,12)}$. The older adult can be classified as dependent (9 to 13 points), semi-dependent (14 to 22 points) or independent (above 22 points) ${ }^{(13)}$.

After the interview, the patient was consulted to record the clinical data about leprosy previous treatment, prior contact, bacillary index, clinical form, treatment regimen, leprosy reaction and Degree of Disability. Disability ranges from zero to two, considering the following: grade zero disability - no problem in the eyes, hands and/or feet resulting from leprosy; grade 1 disability - decrease or loss of protection sensitivity in the eyes, hands or feet; and grade 2 disability - impaired visual acuity, lagophthalmos and/or ectropion, trichiasis and/or central corneal opacity, as well as the presence of trophic and/ or traumatic lesions, claw hands, absorption and disabilities such as the wrist drop and the foot drop ${ }^{(2)}$.

\section{Analysis of results and statistics}

The data were stored and organized in an electronic spreadsheet. Statistical analysis was performed using SPSS software, version 17.0. The frequencies of the variables and their respective confidence intervals were included. The likelihoodratio test was used to investigate the association between socio-demographic and clinical variables and the functional capacity.

\section{RESULTS}

The mean age of the $77(100 \%)$ older adults was 68.23 $( \pm 6.11)$ years. There was a prevalence of men, $49(63 \%)$; in stable union/married, 51 (66.2\%); from Fortaleza, 46 (59.7\%); living with spouse and child(ren), 41 (53.2\%). The mean number of cohabitants was $3.79( \pm 1.98)$, with predominance of the category three to four people, 35 (45.5\%). Regarding education, there was a mean of 4.1 years of formal education; regarding occupation, $51(66.2 \%)$ were retired. The mean monthly family income was of 2.0 minimum wages ${ }^{1}$.
Table 1 - Distribution of the clinical features of older adults with leprosy, Fortaleza, Ceará, Brazil, 2015

\begin{tabular}{|c|c|c|}
\hline Variáveis $(N=77)$ & $\mathbf{n}$ & $\%$ \\
\hline \multicolumn{3}{|l|}{ Comorbidities $(n=55)$} \\
\hline Systemic hypertension & 31 & 56.3 \\
\hline Diabetes mellitus & 23 & 41.8 \\
\hline Cataract & 21 & 38.1 \\
\hline Hypercholesterolemia & 13 & 23.6 \\
\hline Arthritis/Arthrosis & 10 & 18.1 \\
\hline Others & 9 & 16.3 \\
\hline Hearing or visual impairment & 4 & 7.2 \\
\hline Post-Stroke Sequelae & 3 & 5.4 \\
\hline Osteoporosis & 2 & 2.6 \\
\hline \multicolumn{3}{|l|}{$\mathrm{BMI} X=26.03 \mathrm{~S}=3.85$} \\
\hline Normal & 37 & 48.1 \\
\hline Overweight & 23 & 41.8 \\
\hline Underweight & 17 & 22.1 \\
\hline \multicolumn{3}{|c|}{ Blood glucose $(\mathrm{mg} / \mathrm{dL}) \mathrm{X}=108.14 \mathrm{~S}=49.39$} \\
\hline Normal & 50 & 64.9 \\
\hline Impaired glucose tolerance & 15 & 19.5 \\
\hline Diabetes mellitus & 12 & 15.6 \\
\hline \multicolumn{3}{|l|}{ Blood pressure } \\
\hline Prehypertension & 22 & 28.6 \\
\hline Isolated systolic hypertension & 20 & 25.9 \\
\hline Great & 14 & 18.2 \\
\hline Normotensive & 11 & 14.3 \\
\hline Stage 1 hypertension & 8 & 10.4 \\
\hline Stage 2 hypertension & 2 & 2.6 \\
\hline \multicolumn{3}{|l|}{ Had previous treatment for leprosy } \\
\hline No & 64 & 83.1 \\
\hline Yes & 13 & 16.9 \\
\hline \multicolumn{3}{|c|}{ Had previous contact with person with leprosy } \\
\hline No & 52 & 67.5 \\
\hline Yes & 25 & 32.5 \\
\hline \multicolumn{3}{|l|}{ Bacillary index $x=1.49 \mathrm{~S}=1.74$} \\
\hline Positive & 40 & 51.9 \\
\hline Negative & 37 & 48.1 \\
\hline \multicolumn{3}{|l|}{ Form of disease } \\
\hline Dimorphic & 40 & 51.9 \\
\hline Virchowian & 19 & 24.7 \\
\hline Tuberculoid & 15 & 19.5 \\
\hline Indeterminate & 3 & 3.9 \\
\hline \multicolumn{3}{|l|}{ Treatment regimen } \\
\hline Multibacillary & 53 & 68.8 \\
\hline Paucibacillary & 18 & 23.4 \\
\hline Alternative & 6 & 7.8 \\
\hline \multicolumn{3}{|l|}{ Leprosy reaction } \\
\hline No & 62 & 80.5 \\
\hline Yes & 15 & 19.5 \\
\hline \multicolumn{3}{|l|}{ Degree of Disability } \\
\hline 0 & 46 & 59.7 \\
\hline 1 & 15 & 19.5 \\
\hline 2 & 16 & 20.8 \\
\hline
\end{tabular}

1 The minimum wage per month in Brazil corresponds to $\mathrm{R} \$ 937,00$ reais or U\$ 297,81 American dollars according to the Central Bank of Brazil on April 12 $2^{\text {th }}, 2017$. 
Table 2 - Katz Index and Lawton and Brody Scale items and classification of older adults with leprosy regarding functional capacity, Fortaleza, Ceará, Brazil, 2015

\begin{tabular}{|c|c|c|c|c|c|c|}
\hline Katz Index & Yes & No & Lawton and Brody Scale & Unable & $\begin{array}{c}\text { Needs } \\
\text { assistance }\end{array}$ & Independent \\
\hline Bathing & $75(97.4 \%)$ & $02(2.6 \%)$ & Using the telephone & $10(13.0 \%)$ & $12(15.6 \%)$ & $55(71.4 \%)$ \\
\hline Dressing & $73(94.8 \%)$ & $04(5.2 \%)$ & Going to distant places & $07(9.1 \%)$ & $20(26.0 \%)$ & $50(64.9 \%)$ \\
\hline Toileting & $74(96.1 \%)$ & $03(3.9 \%)$ & Shopping & $06(7.8 \%)$ & $16(20.8 \%)$ & $55(71.4 \%)$ \\
\hline Transferring & $74(96.1 \%)$ & $03(3.9 \%)$ & Preparing food & $14(18.2 \%)$ & $15(19.5 \%)$ & $48(62.3 \%)$ \\
\hline Continence & $72(93.5 \%)$ & $05(6.5 \%)$ & Housekeeping & $19(24.7 \%)$ & $14(18.2 \%)$ & $44(57.1 \%)$ \\
\hline \multirow[t]{4}{*}{ Feeding } & $75(97.4 \%)$ & $02(2.6 \%)$ & Making small home repairs & $17(22.1 \%)$ & $19(24.7 \%)$ & $41(53.2 \%)$ \\
\hline & & & Doing laundry and ironing & $21(27.3 \%)$ & $16(20.8 \%)$ & $40(51.9 \%)$ \\
\hline & & & Handling medication & $06(7.8 \%)$ & $17(22.1 \%)$ & $54(70.1 \%)$ \\
\hline & & & Handling finances & $05(6.5 \%)$ & $20(26.0 \%)$ & $52(67.5 \%)$ \\
\hline $\begin{array}{l}\text { Katz Index classification } \\
\text { Katz } X=1.03 S=0.16\end{array}$ & $\mathrm{n}^{\mathbf{o}}$ & $\%$ & $\begin{array}{l}\text { Lawton and Brody Scale classification } \\
X=22.34 S=4.77\end{array}$ & $n^{o}$ & \multicolumn{2}{|c|}{$\%$} \\
\hline Independent & 67 & 87 & Independent & 45 & \multicolumn{2}{|c|}{58.5} \\
\hline Partially dependent & 7 & 9.1 & Semi-dependent & 27 & \multicolumn{2}{|c|}{35} \\
\hline Dependent & 3 & 3.9 & Dependent & 5 & \multicolumn{2}{|c|}{6.5} \\
\hline
\end{tabular}

According to the table above, $55(71.4 \%)$ of the participants had comorbidities. Of these, 31 (56.3) had hypertension, $23(41.8 \%)$ had diabetes mellitus and $21(38.1 \%)$ had cataract. The mean blood glucose level was $108.41 \mathrm{mg} / \mathrm{dL}$ and $50(64.9 \%)$ of the blood glucose levels were classified as "normal". Regarding blood pressure, 22 (28.6\%) were classified as "prehypertension". Regarding the Body Mass Index $(\mathrm{BMI}), 37(48.1 \%)$ were classified as normal. Regarding leprosy, $64(83.1 \%)$ participants reported having no previous history of treatment and $52(67.5 \%)$ had no prior contact with a person with the disease. There was a predominance of intrafamily contact in $20(80.0 \%)$ out of the $25(32.5 \%)$ cases with previous contact with the disease. A positive bacillary index was found in $40(51.9 \%)$ participants, with a small difference in relation to negative indexes, $37(48.1 \%)$. This is related to the concentration of dimorphic cases, 40 (51.9\%), and of the multibacillary treatment, $53(68.8 \%)$. Six $(7.8 \%)$ of the older adults were in an alternative treatment due to complications related to Dapsone, mainly hemolytic anemia. Leprosy reactions occurred in 15 (19.5\%) of the cases, with predominance of the reversal reaction (86.6\%). Most of the participants, 46 $(59.7 \%)$, presented grade zero; however, a considerable percentage of the cases, $31(40.3 \%)$, presented some degree of physical disability.

Table 2 displays the assessment of functional capacity.

According to Table 2, the Katz scale presented a mean score of $1.03( \pm 0.16)$, with prevalence of the classification "independent" $(67 ; 87.0 \%, 95 \% \mathrm{Cl}=76.9$ - 93.2). The activities most performed without barriers were "bathing" and "feeding", both with $75(97.4 \%)$ positive responses, and the most difficult activities were "continence" (05; 6.5\%) and "dressing" (4; 5.2\%).
The Lawton and Brody scale presented a mean of $22.34( \pm$ 4.77) points, with the "independent" classification prevailing in 45 older adult subjects (58.5\%) (Table 2). In all the questions, the answer "independent" was predominant. The items with the highest "needs assistance" answers were those related to mobility and handling finances, both with 20 (26.0\%) answers. As for the answer "unable", there was a concentration in the item "doing laundry and ironing", 21 (27.3\%), followed by the item "Housekeeping", 19 (24.7\%), both referring to domestic activities.

Regarding the association of the functional capacity classifications by the Katz Index and the Lawton and Brody scale and socio-demographic and clinical variables, for activities of daily living only the variable "family income" presented association with the Katz index classification $(p=0.011)$. Total independence reached $92.0 \%(n=23)$ of the older adults with less than 1 minimum wage income; $85.7 \%(n=06)$ of the older adults with more than three minimum wages income; and $84.4 \%$ of the older adults $(\mathrm{n}=38)$ with incomes between 1 and 2 minimum wages.

Regarding the Lawton and Brody Scale, Table 2 shows that the variables "age" ( $p$ 0.012), "living arrangement" ( $p$ 0.031) and "educational attainment" ( $p$ 0.041) were associated with the dependent and independent classifications for instrumental activities.

Regarding Table 3, for the "age" variable there is a decrease in independence related to older ages, while the "living arrangement" variable showed an increase in dependence related to the number of people available to help at home and their kinship with the older adults. However, it was observed that higher levels of educational attainment led to greater independence of the older adults. 
Table 3 - Distribution of the older adults with leprosy according to the Lawton and Brody Scale and associated categorical variables, Fortaleza, Ceará, Brazil, 2015

\begin{tabular}{|c|c|c|c|}
\hline Variables & Dependent & Independent & $p^{*}$ value \\
\hline \multicolumn{4}{|l|}{ Age } \\
\hline $60-64(n=25)$ & $01(4.0 \%)$ & $24(94.0 \%)$ & 0.012 \\
\hline $65-70(n=28)$ & - & $28(100.0 \%)$ & \\
\hline $71-83(n=24)$ & $04(16.6 \%)$ & $20(83.4 \%)$ & \\
\hline \multicolumn{4}{|l|}{ Living arrangement } \\
\hline Only with (a) child(ren) $(\mathrm{n}=08)$ & $01(12.5 \%)$ & $07(87.5 \%)$ & 0.031 \\
\hline Spouse/partner $(\mathrm{n}=07)$ & $01(14.2 \%)$ & $06(85.8 \%)$ & \\
\hline Living alone $(\mathrm{n}=06)$ & $01(16.6 \%)$ & $05(83.4 \%)$ & \\
\hline Spouse and child(ren) $(n=41)$ & $19(46.3 \%)$ & $22(53.7 \%)$ & \\
\hline Other family arrangements $(\mathrm{n}=10)$ & $06(60.0 \%)$ & $04(40.0 \%)$ & \\
\hline Three generation arrangement $(n=05)$ & $04(80.0 \%)$ & $01(20.0 \%)$ & \\
\hline \multicolumn{4}{|l|}{ Educational attainment } \\
\hline Elementary education incomplete or completed $(n=39)$ & $12(30.7 \%)$ & $27(69.3 \%)$ & 0.041 \\
\hline Secondary education incomplete or completed $(\mathrm{n}=16)$ & $06(37.5 \%)$ & $10(62.5 \%)$ & \\
\hline No schooling $(n=22)$ & $14(63.6 \%)$ & $08(36.4 \%)$ & \\
\hline
\end{tabular}

Table 4 - Lawton and Brody Scale Items associated to socio-demographic and clinical variables, Fortaleza, Ceará, Brazil, 2015

\begin{tabular}{|c|c|}
\hline Lawton and Brody Scale & $p^{*}$ value \\
\hline \multicolumn{2}{|l|}{ Using the telephone } \\
\hline Cohabitants & 0.043 \\
\hline Educational attainment & 0.006 \\
\hline \multicolumn{2}{|l|}{ Going to distant places } \\
\hline Age & 0.013 \\
\hline Body Mass Index & 0.010 \\
\hline \multicolumn{2}{|l|}{ Shopping } \\
\hline Age & 0.021 \\
\hline \multicolumn{2}{|l|}{ Preparing food } \\
\hline Age & 0.020 \\
\hline Systemic Blood Pressure & 0.008 \\
\hline Cohabitants & 0.024 \\
\hline \multicolumn{2}{|l|}{ Housekeeping } \\
\hline Age & 0.037 \\
\hline Marital status & 0.048 \\
\hline Cohabitants & 0.012 \\
\hline \multicolumn{2}{|l|}{ Making small home repairs } \\
\hline Body Mass Index & 0.037 \\
\hline Positive leprosy reaction & 0.050 \\
\hline \multicolumn{2}{|l|}{ Handling medication } \\
\hline Blood glucose & 0.019 \\
\hline Blood pressure & 0.026 \\
\hline Bacillary index & 0.013 \\
\hline
\end{tabular}

Note: * Likelihood-ratio test.

Table 4 shows the association of Lawton and Brody scale items with socio-demographic and clinical variables.

Regarding Table 4, the activity "using the telephone" presented an association with the variables "living arrangement" $(p=0.043)$ and "educational attainment" $(p=0.006)$, revealing that all the older adults who lived only with their children performed the activity unassisted, while 04 (40.0\%) of the older adults in a three generation living arrangement and 02 $(40.0 \%)$ of the older adults in other arrangements were unable to perform it. It was observed that $34(87.2 \%)$ of the older adults with incomplete or complete Elementary School were able to perform the activity without help, while 07 (31.8\%) of the older adults with no formal education failed to perform it.

The ability of "going to distant places" was associated with "age" ( $p=0.013)$ and "BMI" ( $p=0.010) ; 22$ (78.6\%) older adults between 65 and 70 years old performed this activity without help. On the other hand, the older adults between 71 and 83 years old found this activity more difficult to perform, since nine $(37.5 \%)$ needed partial assistance and five $(20.8 \%)$ were not able to do it. Most older adults with normal weight $(26 ; 70.3 \%)$ and underweight $(12 ; 70.6 \%)$ performed this activity without help, whereas the need for help was more present in the overweight older adults (10; 43.4\%).

The ability of "shopping" ( $p=0.021)$ was associated with "age", and was performed without help in the majority of cases by the older adults between 65 and 70 years old, 24 $(85.7 \%)$, while "inability to perform it" was the most reported answer by those between 71 and 83 years old, 03 (12,5\%).

The activity "preparing food" showed association with "age" ( $p=0.020)$, "living arrangement" ( $p=0.024)$, and "blood pressure" ( $p=0.008)$. Twenty-three (82.1\%) older adults individuals aged between 65 and 70 years, living with a spouse/partner, $06(85.7 \%)$, and with normal blood pressure, $10(90.1 \%)$, performed the activity predominantly without help. The inability to execute the activity found higher percentages in the older adults between 71 and 83 years old, $08(33.3 \%)$; and in those living in other family arrangements, $04(40.0 \%)$; and in one (50\%) with stage 2 hypertension.

Considering the elderly's ability to perform household activities, the "housekeeping" variable was also associated with "age" $(p=0.037)$, with "living arrangement" $(p=0.012)$, and with 
"marital status" ( $p=0.048)$. The majority of the older adults aged between 65 and 70 years old (71.4\%) did not need assistance for the execution of this activity; the largest number of reports of inability to execute this activity was among the older adults between 71 and 83 years old, 10 (41.7\%). Still, 6 (100\%) of the older adults living alone performed this activity without help; and among the older adults living in other family arrangements, 06 (60.0\%) could not perform this domestic activity. As for the civil status, the single (3; $100.0 \%$ ) and the widowed $(13 ; 76.5 \%)$ did not present any difficulties regarding housekeeping, whereas the divorced were the majority, 03 (50.0\%) were unable to perform the activity.

The ability to make small home repairs was associated with "BMI" ( $p=0.037)$ and "presence of leprosy reaction" $(p=$ $0.050)$ : underweight $(06 ; 35.3 \%)$ or overweight $(07 ; 30.4 \%)$, and with leprosy reaction $(07,46.7 \%)$. Elderly patients with normal weight $(22 ; 59.5 \%)$ and no leprosy reaction (35$56.5 \%$ ) were able to perform this activity without help.

As to the "ability to handle the proper use of prescribed medication", there was an association with "blood pressure" $(p=0.026)$, "blood glucose" $(p=0.019)$ and "bacillary in$\operatorname{dex}^{\prime \prime}(p=0.013)$; older adults with normal blood pressure and glucose did not present difficulties in this activity, as well as elderly patients with negative bacillary index.

\section{DISCUSSION}

The findings of this study demonstrated that the older adults with leprosy have socio-demographic features similar to the older adults without the disease. Conditions such as low income and low educational attainment prevailed, characteristics linked to the onset of the disease. The clinical characteristics related to leprosy in the participants were in agreement with the findings of other studies addressing non-elderly leprosy patients ${ }^{(14-15)}$.

The functional capacity of the older adults with leprosy in this study was satisfactory, and it did not directly influence the disease and the disability caused by it. However, new studies must be developed to address this relation, since the high number of participants with no disability in this study might explain this result. This result is consonant with a study that addressed the functional capacity of older adults ${ }^{(16)}$.

The associations found between functional capacity and socio-demographic and clinical characteristics are similar to the findings of other studies addressing older adults with other chronic conditions in the basic health care network. A study conducted with 388 older adults, using Katz Index and Lawton and Brody scale to assess predictive factors for functional incapacity, verified that functional incapacity for basic activities was associated with age and ethnicity and functional incapacity for instrumental activities was associated with age, educational attainment, income and health self-assessment ${ }^{(17)}$.

Another important finding is the association between age and the functional capacity of going to distant places, shopping and preparing meals. Studies show that all these activities can be affected by aging, which can be explained by the correlation between them: the act of going shopping is related to other factors, such as need for moving to distant places, ability to handle money and ability to carry the bought items.
Therefore, the prevalence of functional limitation in older ages is related to the natural changes of the aging process and to infrastructure factors such as streets and sidewalks architecture and urban transportation ${ }^{(18)}$.

Older adults living only with their children might have the role of provider for the family and need to develop skills such as using the television, the appliances and the telephone. The level of education has a fundamental role in the ability to acquire new knowledge, including using new technologies; therefore, there is a strongly positive correlation between years of formal education and better health conditions and self-care habits. ${ }^{(19)}$.

In the older adults in this study the variables "advanced age", "living in other family arrangements" and "having level 2 hypertension" were factors that impaired the performance of instrumental activities. These factors demonstrate the reality of older adults with comorbidities and need for assistance, since household/instrumental activities require greater effort and physical capacity, aspects impaired by aging and by the presence of comorbidities ${ }^{(20)}$. In this subject, studies show association between low functional capacity and elevated blood pressure levels ${ }^{(21)}$.

Regarding the BMI, studies show association between nutritional status and functional dependence, reinforcing the findings of this study. Other studies show that underweight older adults had a dependence prevalence ratio 1.2 times higher than those with normal weight ${ }^{(22)}$. Association between weight and ability to do small home repairs points to a possible decrease of muscle mass related to low weight and difficulties to perform activities that require physical effort for the overweight older adults.

Ability to do small repairs was associated with leprosy reaction. This result was expected, since this reaction might manifest with neuritis, hand edema, fever and malaise; this signs and symptoms can impair the performance of activities that require greater physical effort, thus interfering in the quality of life ${ }^{(23)}$.

Inability to manage the use of prescribed medication was associated with situations in which blood pressure and blood glucose were not controlled and the bacillary index was positive. The difficulty to follow the prescribed treatment involves the patient's predisposition and cognitive ability to understand the therapeutic treatment. These factors might be aggravated by the presence of comorbidities, since the patient needs to manage a larger number of medications. Added to this, the socio-demographic features presented by the older adults in this study increase this situation ${ }^{(24)}$.

\section{Study limitations}

The cross-sectional design of this study is highlighted as a limitation, since it does not allow following situations related to environmental and behavioral factors, which could influence the process and installation of functional limitations in the participants. Therefore, future studies should follow and assess the influence of extrinsic factors on the decline of functional capacity in older adults with leprosy.

\section{Contributions to areas of nursing, health or public policy}

The growing prevalence of leprosy cases in older adults demands knowledge and preparation from health professionals, especially nursing professionals, in order to provide comprehensive care to these subjects. Thus, the evaluation of functional capacity 
aspects should be included in older adults who were not evaluated according to the recommendations for patients with leprosy, also aiming to preserve the functionality and independence of patients.

\section{CONCLUSION}

Regarding the assessment of functional capacity, it is noteworthy that the majority of the older adults with leprosy in the instruments used were independent. In addition, the instruments pointed to a greater number of associations with sociodemographic and clinical factors not related to leprosy.

Therefore, the importance of developing care for older adults with leprosy around the specific care needs of this stage of life is identified, so that they receive care and actions according to the pre-existing functional limitations that can be increased and/or aggravated by disabilities caused by leprosy.

\section{REFERENCES}

1. Carneiro JA, Ramos GC, Barbosa AT, Mendonça JM, Costa FM, Caldeira AP. Prevalence and factors associated with frailty in noninstitutionalized older adults. Rev Bras Enferm [Internet]. 2016 [cited 2017 Feb 14];69(3):435-42. Available from: http://dx.doi. org/10.1590/0034-7167.2016690304i

2. Brasil. Ministério da Saúde. Secretaria de Vigilância em Saúde. Departamento de Vigilância das Doenças Transmissíveis. Diretrizes para vigilância, atenção e eliminação da Hanseníase como problema de saúde pública: manual técnico-operacional [Internet]. Ministério da Saúde, Brasília (DF); 2016. [cited 2017 Feb 08]. Available from: https://central3.to.gov.br/arquivo/297694/http:// apps.who.int/iris/bitstream/10665/249601/1/WER9135.pdf?ua =1

3. World Health Organization (WHO). Weekly Epidemiological Record [Internet]. 2016 [cited 2017 Feb 08];91(35):441-60. Available from:http://apps.who.int/iris/bitstream/10665/249601/1/WER9135.pdf?ua =1

4. Brasil. Ministério da Saúde. Sistema de Informação de Agravos Notificáveis/SINAN. Registro ativo: número e percentual. Casos novos de hanseníase: número, coeficiente e percentual, faixa etária, classificação operacional, sexo, grau de incapacidade, contatos examinados, por estados e regiões[Internet]. Brasília: SINAN; 2015. [cited 2017 Feb 08]. Available from: http://portalarquivos. saude.gov.br/images/pdf/2016/julho/07/tabela-geral-2015.pdf

5. Brasil. Senado Federal. Lei $\mathrm{n}^{\circ} 10.741$, de $1^{\circ}$ de outubro de 2003. Dispõe sobre o Estatuto do Idoso e dá outras providências[Internet]. Brasília (DF): Senado Federal. 2003 [cited 2017 Feb 08]. Available from: http://www.planalto.gov.br/ccivil 03/leis/2003/l10.741. htm

6. Sociedade Brasileira de Cardiologia (SBC). Sociedade Brasileira de Hipertensão. Sociedade Brasileira de Nefrologia. VII Diretrizes Brasileiras de Hipertensão Arterial. Arq Bras Cardiol [Internet]. 2016 [cited 2017 Feb 08];107(3):1-83. Available from: http:// publicacoes.cardiol.br/2014/diretrizes/2016/05_HIPERTENSAO_ARTERIAL.pdf

7. Oliveira JEP, Vencio S. Diretrizes da Sociedade Brasileira de Diabetes: 2015-2016 [Internet]. São Paulo: AC Farmacêutica; 2016 [cited 2017 Feb 08]. Available from: http://www.diabetes.org.br/sbdonline/images/docs/DIRETRIZES-SBD-2015-2016.pdf

8. Brasil. Ministério da Saúde. Secretaria de Atenção à Saúde. Departamento de Atenção Básica. Envelhecimento e saúde da pessoa idosa. Brasília: Ministério da Saúde; 2007.

9. Katz S, Ford AB, Moskowitz RW, Jackson BA, Jaffe MW. Studies of illness in the aged: the index of ADL: a standardized measure of biological and psychosocial function. JAMA[Internet]. 1963 [cited 2017 Feb 08];185(12):914-9. Available from: http://dx.doi. org/10.1001/jama.1963.03060120024016.

10. Duarte YA, Andrade CL, Lebrão ML. Katz Index on elderly functionality evaluation. Rev Esc Enferm USP [Internet]. 2007 [cited 2017 Feb 08];41(2):317-25. Available from: http://dx.doi.org/10.1590/S0080-62342007000200021

11. Wallace M, Shelkey M. Katz index of independence in activities of daily living (ADL). Nursing Clinics of North America. 2007;39(3):473-93.

12. Freitas EV, Miranda RD, Nery MR. Parâmetros clínicos do envelhecimento e avaliação geriátrica global. In: Freitas EV. Tratado de geriatria e gerontologia. Rio de Janeiro: Guanabara-Koogan, 2006. p.900-9,

13. Lawton MP, Moss M, Fulcomer M, Kleban MH. A research and service oriented multilevel assessment instrument. J Gerontol [Internet]. 1982 [cited 2017 Feb 08];1;37(1):91-9. Available from: https://doi.org/10.1093/geronj/37.1.91

14. Viana LS, Aguiar MIF, Aquino DMC. Social-epidemiologic and clinical profile of elderly people affected by leprosy: contributions to nursing. Rev Pesqui Cuid Fundam [Internet]. 2016 [cited 2017 Feb 08];1;8(2):4435-46. Available from: http://www.seer.unirio. br/index.php/cuidadofundamental/article/view/4593/pdf 1895

15. Brito KKG, Aguiar ESS, Diniz IV, Silva MA, Soares. Caracterização da hanseníase na população idosa da Paraíba. In: Anais do 4th International Congress of Human Aging; 2015 set. 21-26; Campina Grande, Brasil. Campina Grade: Centro Multidisciplinar de Estudos e Pesquisas (CEMEP) da Universidade Estadual da Paraíba (UEPB); 2015 [cited 2017 Feb 08];2(1):1-9. Available from: http://www.editorarealize.com.br/revistas/cieh/trabalhos/TRABALHO_EV040_MD2_SA2_ID674_14072015170733.pdf

16. Fialho CB, Costa MF, Giacomin KC, Loyola Filho AI. [Disability and use of health services by the elderly in Greater Metropolitan Belo Horizonte, Minas Gerais State, Brazil: a population-based study]. Cad Saúde Pública [Internet]. 2014 [cited 2017 Feb 
13];30(3):599-610. Available from: http://www.scielo.br/pdf/csp/v30n3/0102-311X-csp-30-3-0599.pdf Portuguese.

17. Pereira LC, Figueiredo MLF, Beleza CMF, Andrade EMLR, Silva MJ, Pereira AFM. Fatores preditores para incapacidade funcional de idosos atendidos na atenção básica. Rev Bras Enferm [Internet]. 2017 [cited 2017 Feb 08];70(1):112-8. Available from: http:// www.scielo.br/pdf/reben/v70n1/en_0034-7167-reben-70-01-0112.pdf

18. Pinto JM, Neri AL. Chronic diseases, functional ability, social involvement and satisfaction in community-dwelling elderly: the Fibra study. Cienc Saude Colet [Internet]. 2013 [cited 2017 Feb 08];18(12):3449-60. Available from: http://taurus.unicamp.br/ bitstream/REPOSIP/42148/1/S1413-81232013001200002.pdf

19. Pinheiro PA, Passos TD, Coqueiro RD, Fernandes MH, Barbosa AR. Motor performance of the elderly in northeast Brazil: differences with age and sex. Rev Esc Enferm USP [Internet]. 2013 [cited 2017 Feb 08];47(1):128-36. Available from: http://dx.doi. org/10.1590./S0080-62342013000100016

20. Gonçalves CG, Guedes MB, Lopes JM, Roing JJ, Guedes TS, Assunção Cortez LC, et al. Comparação do perfil entre idosos hipertensos e normotensos no município de Belo Horizonte-MG. Cad Edu Saude Fis [Internet]. 2014 [cited 2017 Feb 08];1(1):1. Available from: http://revista.redeunida.org.br/ojs/index.php/cadernos-educacao-saude fisioterapia/article/view/107

21. Lana LD, Schneider RH. The frailty syndrome in elderly: a narrative review. Rev bras geriatr Gerontol [Internet]. 2014 [cited 2017 Feb 08];17(3):673-80. Available from: http://dx.doi.org/10.1590/1809-9823.2014.12162

22. Andrade ARC, Nery JAC. Episódios reacionais da hanseníase. In: Alves ED, Ferreira TL, Nery I. (eds.) Hanseníase: avanços e desafios. Brasília: NESPROM; 2014. p. 492.

23. Costa MD, Terra FD, Costa RD, Lyon S, Costa AM, Antunes CM. Assessment of quality of life of patients with leprosy reactional states treated in a dermatology reference center. An Bras Dermatol [Internet]. 2012 [cited 2017 Feb 08];87(1):26-35. Available from: http://www.scielo.br/pdf/abd/v87n1/v87n1a03.pdf

24. Duarte LR, Gianini RJ, Ferreira LR, Camargo MA, Galhardo SD. Hábitos de consumo de medicamentos entre idosos usuários do SUS e de plano de saúde. Cad Saúde Colet [Internet]. 2012 [cited 2017 Feb 08];20(1):64-71. Available from: http://iesc.ufrj.br/ cadernos/images/csc/2012_1/artigos/CSC_v20n1_64-71.pdf 